\title{
The Sixth Conference of the African Consortium for Law and Religion Studies: Law, Religion and Human Flourishing
}

\author{
Baze University, Abuja, 20-22 May 2018
}

Mark Hill QC

Extraordinary Professor, University of Pretoria

The African Consortium for Law and Religion Studies (ACLARS) has come a long way - literally and metaphorically - since its establishment in Ghana in 2013 for an inaugural symposium under the leadership of Professor Kofi Quashigah, then Dean of the Law School at the University of Accra. It subsequently reconvened in South Africa (2014), Namibia (2015), Ethiopia (2016) and Morocco (2017). The proceedings of the Morocco meeting, Religion, Law and Security in Africa, have just been published. ${ }^{1}$

The 2018 conference in Nigeria was an ambitious affair. It was preceded by an intensive study programme at Nile University, also in Abuja, hosted by the West African Regional Center for Law and Religion Studies (WARCLARS), under the direction of Professor Akin Ibidapo-Obe, from the Faculty of Law, University of Lagos. The pioneering work of WARCLARS in creating a curriculum for law and religion studies from a uniquely African standpoint was warmly welcomed, and this was presented as part of a separate symposium held at Nile University in the days immediately preceding the ACLARS conference.

Religious leaders were well represented, including Cardinal John Onaiyekan, Roman Catholic Archbishop of Nigeria, and I was privileged to bring greetings from Anglican Archbishop Nicholas Okoh, Primate of All Nigeria, following a private meeting on the Feast of Pentecost. While the focus of the various contributions was on the position within the wide and diverse continent of Africa, there were a number of high-level international contributions, particularly the keynote speech of Jan Figel, EU Special Envoy for the Promotion of Freedom of Religion or Belief outside the European Union. The Nigerian judiciary was similarly well represented, with papers delivered by several justices of the Supreme Court, the Court of Appeals and the Federal High Court. 
The broad theme of law, religion and human flourishing was expansively interpreted. Governmental interactions with Islamic reform movements were considered by one panel, while development and overseas aid were the subject of another. Controversial subjects such as corruption, extremism and forced migration were also the subject of discussion. Gender and marriage were recurring themes in various sessions, as was the impact of news and social media on the concept of human flourishing. Diet and the ritual slaughter of animals also featured, as did indigenous religions, particularly their interaction with Western concepts of human rights.

The best of the papers will be published next year in a collected volume, to add to the growing library of ACLARS conference papers which makes the work and achievement of the Consortium readily available to the academic world and those in positions of leadership or influence. A draft call for papers is already in circulation for next year's conference, to be held at the University of Gaborone in Botswana, addressing law, religion and environment.

doi:10.1017/So956618X18000510

\section{The McDonald Distinguished Christian Scholars Conference: Is Religious Liberty Under Threat? Trans-Atlantic Perspectives}

\section{University of Oxford, 23-25 May 20I8}

JOHN WITTE JR

Director, Center for the Study of Law and Religion, Emory University

Co-hosted by the McDonald Centre at the University of Oxford and the Center for the Study of Law and Religion at Emory University, this public conference featured lectures by a dozen leading scholars from the United States and the United Kingdom. The conference marked the tenth anniversary of the McDonald Centre and was the culminating event in the McDonald Distinguished Christian Scholar Lecture Series, hosted by the Emory Law and Religion Center. The McDonald Agape Foundation provided generous funding.

The conference opened with a keynote address by Mary Ann Glendon, Learned Hand Professor of Law at Harvard Law School, and former 